\title{
Pengaruh Pengalaman Wisatawan Terhadap Minat Berkunjung Kembali Pada Lokasi Dark Tourism - Gunung Kelud, Kediri
}

\section{(The Effect Of Tourist Experience On Revisit Intention In The Dark Torism Location)}

\author{
Yudiarto Perdana Putra1, Nindi Vaulia Puspita \\ ${ }^{1,2}$ Program Studi Manajemen Universitas Kadiri, \\ ${ }^{1}$ yudiarto@unik-kediri.ac.id, ${ }^{2}$ nindi.vaulia@unik-kediri.ac.id
}

\begin{tabular}{l} 
Info Artikel (11 pt) \\
\hline Diterima Agustus 1, 2020 \\
Direvisi Agustus 20, 2020 \\
Dipubikasi September 20, \\
2020
\end{tabular}

\section{Kata Kunci:}

Pengalaman Wisatawan, Minat Berkunjung, Wisata Gelap (bencana).

Keywords :

Tourist Experience, Revisit Intention, Dark Tourism

\begin{abstract}
Abstrak
Penelitian ini dalam pelaksanaannya memiliki tujuan untuk menganalisis hubungan/ korelasi antara variabel pengalaman wisatawan (tourist experience) terhadap minat untuk melakukan kunjungan kembali pada obyek wisata gelap (dark tourism). Dari berbagai macam wisata gelap, penelitian ini mengambil dari segi pasca bencana alam. Metode penelitian analisis statistik, dengan membagikan kuesioner kepada responden dengan sistem random sampling. Adapun hasil penelitian adalah pengalaman wisatawan memiliki pengaruh terhadap minat berkunjung kembali (variabel dependent) pada obyek wisata gelap (dark tourism) baik secara parsial maupun secara simultan. Dari 4 variabel independent, variabel pengalaman dari pengetahuan Memiliki tingkat pengaruh yang paling tinggi terhadap minat berkunjung kembali wisatawan ke kawasan Gunung Kelud.
\end{abstract}

Abstract
The purpose of this study was to analyze the
relationship between tourist experience variables and
the interest in returning to dark tourism objects. From
various kinds of dark tourism, this research takes the
point of view of post-natural disasters. Statistical
analysis research method, by distributing
questionnaires to respondents with a random sampling
system. The results of the research show that the
experience of tourists has an influence on the revisit
intention (dependent variable) on dark tourism objects




\section{JURNAL \\ ANALISIS, PREDIKSI, DAN INFORMASI}

(dark tourism) either partially or simultaneously. Of the 4 independent variables, Knowledge Experiecne variables has the highest level of influence on the interest in returning tourists to the Mount Kelud area.

\section{PENDAHULUAN}

Pariwisata merupakan salah satu sektor ekonomi yang diunggulkan di setiap negara, termasuk Indonesia. Seringkali kita jumpai iklan-iklan terkait dengan potensi pariwisata di negara atau daerah masing-masing. Dikutip dari Asisten Deputi Penelitian \& Pengembangan Kementrian Pariwisata Republik Indonesia, sektor pariwisata ditetapkan sebagai sektor yang penting dan dapat dikembangkan dengan melakukan pembinaan dan bersinergi dengan berbagai sektor unggulan disekitarnya (K. Pariwisata, 2015).

Kunjungan wisatawan mancanegara di Indonesia meningkat sekitar $30 \%$ pada tahun 2017, dibandingkan tahun sebelumnya (K. Pariwisata \& Statistik, 2017). Tentunya juga terus meningkat pada saat sekarang ini. Indonesia memiliki potensi wisata yang sangat beraneka ragam, mulai dari wisata sejarah, wisata alam, wisata olah raga, dan wisata gelap (dark tourism).

Tabel 1. Kunjungan Wisatawan Mancanegara di Indonesia

\begin{tabular}{|c|c|c|}
\hline No & Tahun & Jumlah Wisatawan \\
\hline 1 & 2016 & 11.519 .275 orang \\
\hline 2 & 2017 & 14.039 .799 orang \\
\hline 3 & 2018 & 15.810 .305 orang \\
\hline
\end{tabular}

Sumber : Pariwisata and Statistik (2019)(S. S. Pariwisata, 2019)

Wisata gelap, adalah tindakan bepergian ke lokasi bekas terjadinya suatu peristiwa yang terdiri dari kematian, bencana, dan kekejaman penjajahan (Zhang, Yang, Zheng, \& Zhang, 2016). Dengan cara yang lebih spesifik, pariwisata gelap dianggap sebagai suatau kegiatan wisata dengan mengunjungi lokasi dimana pernah terjadi tragedi atau kejadian kematian yang secara historis penting telah terjadi (bencana alam, perang, dll) dan yang terus berdampak pada kehidupan kita (Tarlow, 2005). Contoh lokasi wisata gelap di Indonesia misalnya, Lubang Buaya, Museum Erupsi Gunung Merapi, Munumen Bom Bali, dan masih banyak lagi. Contoh lain lokasi dark tourism untuk skala internasional adalah peristiwa mengerikan 11 September 2001. Penulis memetakan bentuk-bentuk awal peringatan di Ground Zero hingga Peringatan 9/11 yang sekarang dibuat "11 September 
- National Memorial Museum” (Dalton, 2015).

Dark Tourism dalam lingkup studi internasional sebagai produk pariwisata mulai menarik perhatian peneliti sejak awal 90-an, tetapi belum adanya konseptualisasi dan penunjukan yang khusus (Fonseca, Seabra, \& Silva, 2016). Wisatawan yang mengunjungi lokasi dark tourism menunjukkan adanya emosi dua spektrum, dari terang ke gelap dan dari lemah ke kuat" dan beberapa wisatawan tidak dapat menjawab pertanyaan seperti “bagaimana perasaan saat berkunjung?" (Podoshen, Andrzejewski, Venkatesh, \& Wallin, 2015). Hal tersebut menunjukkan bahwa wisatawan yang mengunjungi lokasi dark tourism pasti memiliki pengalaman tersendiri yang tentunya berbeda jika dibandingkan dengan mengunjungi lokasi wisata lainnya. Dengan adanya pengalaman tersebut, maka diduga aka nada minat untuk berkunjung kembali.

Obyek wisata di Kediri, khsusunya pada wisata Gunung Kelud mengalami peningkatan yang cukup signifikan, terutama setelah letusannya pada 2014. Para wisatawan baik lokal maupun nasional, khususnya di area Pulau Jawa penasaran dengan kondisi Gunung Kelud pasca letusan yang cukup memberikan dampak bagi kondisi nasional. Data menunjukkan pada agenda liburan 3 hari, jumlah pengunjung mencapai 13.326 orang (Liputan6, 2019). Pada 2018 Kota Kediri menargetkan kunjungan wisatwan berjumlah 180.000 wisatawan, untuk menunjang hal tersebut, Pemerintah Kota Kediri membuat Rencana Induk Pengembangan Pariwisata Daerah (RIPPD) (Sari, 2016). Kondisi lokasi wisata yang terintegrasi membuat daya Tarik tersendiri untuk kawasan Gunung Kelud. Wisatawan bia mngunjungi Monumen Simpang Lima Gumul, Sumber air \& kolam renang Ubalan, off road jip, dll. (NUGROHO, 2019).

Letusan Gunung Kelud terjadi pada 13 Februari 2014 pada pukul 22.50 telah terjadi letusan pertama tipe ledakan (eksplosif), dimana suara letusan terdengar hingga radius 30km dari puncak Kelud. Dampak berupa abu vulkanik Gunung Kelud melumpuhkan Jawa. Tujuh bandara di Yogyakarta, Surakarta, Surabaya, Malang, Semarang, Cilacap dan Bandung, ditutup. Dalam bencana erupsi ini tentunya juga terdampak pada kerugian secara material hingga ratusan milliard rupiah (Wikipedia, 2014).

Ada beberapa penelitian terdahulu yang melandasi penelitian ini, yang pertama 


\section{JURNAL \\ ANALISIS, PREDIKSI, DAN INFORMASI}

dengan judul "Sought Experiences At (Dark) Heritage Sites" (Biran, Poria, \& Oren, 2011) penelitian ini berlokasi di wisata gelap kamp kematian saat perang dunia. Yang kedua dengan judul "Dark Tourism Motivations : Simulation, Emotional Contagion And Topographic Comparison" (Podoshen, 2013), penelitian ini terkait dengan wisata gelap yang dipadukan dengan pagelaran seni pertunjukkan music metal. Selanjutnya dengan judul "New Approaches To Dark Tourism Inquiry : A Response To Isaac" (Podoshen et al., 2015), penelitian ini adalah menganalisis bagaimana budaya dari konsumen dalam kunjungan ke wisata gelap.

Penelitian ini dilakukan dengan tujuan untuk menganalisis hubungan/ korelasi antara variabel pengalaman wisatawan (tourist experience) terhadap minat untuk melakukan kunjungan kembali, dengan rincian sebagai berikut : (a) Untuk menganalisis pengaruh moral experience terhadap revisit intention pada obyek dark tourism; (b) Untuk menganalisis pengaruh educational experience terhadap revisit intention pada obyek dark tourism; (c) Untuk menganalisis pengaruh experience ef knowladge terhadap revisit intention pada obyek dark tourism; (d) Untuk menganalisis pengaruh personal experience terhadap revisit intention pada obyek dark tourism; (e) Untuk menganalisis pengaruh secara simultan dari moral experience, educational experience, experience ef knowledge, personal experience terhadap revisit intention pada obyek dark tourism.

Urgensi dari penelitian ini adalah untuk mengetahui beberapa hal yang membuat wisatawan datang kembali pada lokasi dark tourism, karena dengan meningkatnya kunjungan wisatawan, maka secara berkepanjangan akan memberikan dampak peningkatan kehidupan ekonomi masyarakat. Berdasarkan latar belakang dan tujuan tersebut, maka peneliti akan mengambil judul "Pengaruh Pengalaman Wisatawan Terhadap Minat Berkunjung Kembali Pada Lokasi Dark Tourism - Gunung Kelud, Kediri"

\section{METODE PENELITIAN}

\section{Populasi \& Sampel}

Populasi dalam penelitian ini adalah wisatawan yang telah berkunjung minimal 2 kali ke lokasi Dark Tourism di Kediri yang jumlahnya tidak bisa ditentukan. Penentuan 
jumlah sampel menggunakan rumus Lameshow :

$$
n=\frac{z a^{2} x P x Q}{L^{2}}
$$

Keterangan:

$\mathrm{n}=$ Jumlah sampel

$Z \alpha=$ Nilai standar dari distribusi sesuai nilai $\alpha=5 \%=1.96$

$\mathrm{P}=$ Prevalensi outcome, karena data belum didapat, maka dipakai 50\%

$\mathrm{Q}=1-\mathrm{P}$

$\mathrm{L}=$ Tingkat ketelitian

Peneliti menentukan taraf signifikansi 7\%, sehingga diperoleh jumlah sampel 196 responden dengan perhitungan sebagai berikut: $\quad n=\frac{(1,96)^{2} \times 0,5 \times 0,5}{(0,07)^{2}}=196$

\section{Lokasi Penelitian}

Lokasi pada penelitian ini adalah Obyek Wisata Gunung Kelud, Kediri, dimana pada tahun 2014 terjadi bencana letusan vulkanik dimana abunya hingga Jawa Barat \& menyebabkan penutupan beberapa bandara.

\section{Teknik Pengumpulan Data}

Metode pengumpulan data yang akan diteliti adalah dengan teknik Systematic Random Sampling (Sugiyono, 2010) dengan memberikan kuesioner terbuka yang terstruktur. Dalam kuesioner telah dibuatkan daftar pertanyaan yang menyangkut pengalaman wisatawan dalam mengunjungi lokasi dark tourism dan terkait minat untuk mengunjungi kembali lokasi tersebut. Para responden diminta untuk menjawab pertanyaan pada kuesioner dengan skala Likert (poin 1 sepenuhnya tidak setuju, hingga poin 5 setuju sepenuhnya).

\section{Definisi Operasional}

Tabel 2. Definisi Operasional Variabel

\begin{tabular}{|l|l|}
\hline Variabel & Item \\
\hline X1 : & (a) Simpati untuk korban yang meninggal \\
Moral Experience & (b) Simpati bagi orang yang mengalami bencana \\
(Pengalaman Moral) & (c) Berempati dengan cedera mental dan fisik para korban. \\
\hline X2: & (a) Dukungan dalam penjelasan pendidikan bencana sangat \\
Education Experience & penting. \\
(Pengalaman Pendidikan & (b) Kesadaran akan pencegahan bencana sangat penting \\
\hline
\end{tabular}




\section{JURNA \\ ANALISIS, PREDIKSI, DAN INFORMASI}

\begin{tabular}{|l|l|}
\hline $\begin{array}{l}\text { X3: } \\
\text { Knowledge Experience } \\
\text { (pengalaman } \\
\text { pengetahuan) }\end{array}$ & $\begin{array}{l}\text { (a) Dampak gempa itu serius } \\
\text { (b) Gempa bumi menghasilkan banyak korban }\end{array}$ \\
\hline X4: & \\
$\begin{array}{l}\text { Personal Experience } \\
\text { (Pengalaman Pribadi) }\end{array}$ & $\begin{array}{l}\text { (a) Ada keterlibatan pribadi dalam bencana yang terjadi } \\
\text { (c) Menghargai kualitas hidup saat ini. }\end{array}$ \\
\hline $\begin{array}{l}\text { Y: } \\
\text { Revisit Intention }\end{array}$ & (a) Mengunjungi tujuan ini lagi \\
$\begin{array}{l}\text { Minat Berkunjung } \\
\text { Kembali (b) Merekomendasikan kepada orang lain. }\end{array}$ & \\
\hline
\end{tabular}

Sumber : (Yan, Zhang, Zhang, Lu, \& Guo, 2016)

\section{Analisis Data}

Berdasarkan metode pengumpulan data diatas, maka untuk analisis data peneliti menggunakan metode sebagai berikut:

\section{Uji Validitas}

Setiap kuesioner harus diukur valid atau tidak validnya suatu data, yaitu dengan analisis uji validitas (Nasution, 2011). "Suatu kuesioner dikatakan valid jika pertanyaan pada kuesioner mampu untuk mengungkapkan sesuatu yang akan diukur oleh kuesioner tersebut" (Ghozali, 2005). Kriteria pengambilan keputusan dengan $\alpha=5 \%$, maka data dinyatakan valid jika memiliki nilai signifikasi $<0,05$. Untuk melalukan uji validitas dapat menggunakan rumus sebagai berikut:

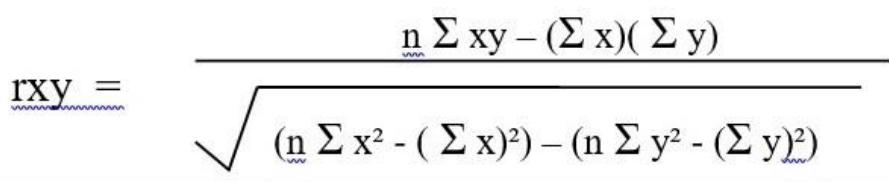

\section{Dimana:}

$\mathrm{r} \quad=$ Koefisien korelasi

$\mathrm{n} \quad=$ Banyaknya sampel

$\Sigma \mathrm{xy}=$ Jumlah perkalian Variabel $\mathrm{X}$ dan $\mathrm{Y}$

$\Sigma \mathrm{x} \quad=$ Jumlah nilai variabel $\mathrm{X}$

$\Sigma \mathrm{y}=$ Jumlah nilai variabel $\mathrm{Y}$

$\Sigma \mathrm{X}^{2}=$ Jumlah pangkat dua nilai variabel $\mathrm{X}$

$\Sigma \mathrm{y}^{2}=$ Jumlah pangkat dua nilai variabel $\mathrm{Y}$

Dalam uji instrument, validitas dari kuesioner, peneliti menguji kuesioner dengan 30 sampel. Dari hasil uji di SPSS, dinyatakan semua item valid, dengan hasil seperti tabel 
Tabel 3. Hasil Uji Validitas

\begin{tabular}{|c|c|c|c|c|c|}
\hline Variabel & Nilai & Keterangan & Variabel & Nilai & Keterangan \\
\hline X1.1 & 0,880 & Valid & X3.2 & 0,879 & Valid \\
\hline X1.2 & 0,773 & Valid & X4.1 & 0,859 & Valid \\
\hline X1.3 & 0,685 & Valid & X.4.2 & 0,847 & Valid \\
\hline X2.1 & 0,908 & Valid & X.4.3 & 0,736 & Valid \\
\hline X2.2 & 0,881 & Valid & Y1.1 & 0,866 & Valid \\
\hline X3.1 & 0,825 & Valid & Y1.2 & 0,879 & Valid \\
\hline
\end{tabular}

Sumber: data diolah peneliti (2020)

\section{Uji Reliabilitas}

Uji Reliabilitas adalah suatu alat untuk mengukur suatu hasil penelitian, jika dilakukan pada waktu-waktu yang berbeda/ berlainan, haruslah memiliki hasil yang sama. Triton mengemukakan bahwa skala itu dikelompokkan ke dalam lima kelas dengan reng yang sma, maka ukuran kemantapan alpha dapat di interprestasikan sebagai berikut (Sujianto, 2009):

1. Nilai Cronbach's Alpha 0,00 sampai dengan 0,20 berarti kurang reliabel.

2. Nilai Cronbach's Alpha 0,21 sampai dengan 0,40 berarti agak reliabel.

3. Nilai Cronbach's Alpha 0,41 sampai dengan 0,60 berarti cukup reliabel.

4. Nilai Cronbach's Alpha 0,61 sampai dengan 0,80 berarti reliabel.

5. Nilai Cronbach's Alpha 0,81 sampai dengan 1,00 berarti sangat reliabel.

Dalam uji instrument, reliabilitas dari kuesioner, peneliti menguji kuesioner dengan 30 sampel. Dari hasil uji di SPSS, dinyatakan semua item reliabel, dengan hasil seperti tabel 4.

\section{Tabel 4. Nilai Uji Reliabilitas}

\begin{tabular}{|c|c|c|}
\hline Variabel & Nilai & Keterangan \\
\hline $\mathrm{X} 1$ & 0,685 & Reliabel \\
\hline $\mathrm{X} 2$ & 0,749 & Reliabel \\
\hline $\mathrm{X} 3$ & 0,620 & Reliabel \\
\hline $\mathrm{X} 4$ & 0,746 & Reliabel \\
\hline $\mathrm{Y}$ & 0,686 & Reliabel \\
\hline
\end{tabular}

Sumber: data diolah peneliti (2020) 


\section{JURNA \\ ANALISIS, PREDIKSI, DAN INFORMASI}

\section{Uji Analisis Data}

\section{Uji Normalitas}

Setiap penelitian harus diketahui apakah data variabel yang digunakan normal atau tidak, yaitu memalui uji normalitas. Untuk melakukan parametric-test, salah satu syaratnya adalah data yang digunakan berdistribusi normal (Sujianto, 2009). Dasar Pengambilan Keputusan Uji Normalitas:

a. "Data berdistribusi normal, jika nilai sig (signifikansi) $>0,05$

b. Data berdistribusi tidak normal, jika nilai sig (signifikansi) $<0,05$ ”.

\section{Uji Multikolinearitas}

Munculnya multikolinearitas dikarenakan adanya hubungan kausal antara dua atau lebih variabel bebas (independent) atau adanya kenyataan bahwa dua variabel penjelas atau lebih bersama-sama dipengaruhi oleh variabel ketiga yang berada di luar model (Sujianto, 2009). Mendeteksi ada atau tidaknya multikolinearitas, dapat dilihat jika nilai Variance Inflation Factor (VIF) $<10$ maka model bisa dikatakan terbebas dari multikolinearitas (Sujianto, 2009).

\section{Uji Heteroskedastisitas}

Uji ini digunakan untuk mengetahui apakah sebuah model regresi memiliki indikasi heteroskedastisitas dengan cara meregres absolute residual. Dalam sebuah model regresi, harus tidak ada gejala heteroskedastisitas. Deteksi ada atau tidaknya heteroskedastisitas dapat dilakukan dengan melihat hasil signifikansi dari tabel Coefficients. Jika nilai signifikasi antara variable independen dengan absolute residualnya lebih dari 0,05 memiliki makna tidak terjadi heteroskedastisitas.

\section{Regresi Linear Berganda}

Penelitian ini, untuk mengetahui variabel bebas (X) dalam mempengaruhi oleh variabel terikat $(\mathrm{Y})$. Alat analisis yang digunakan dalam penelitian ini adalah regresi berganda (Mauludi, 2016). Rumus persamaan regresi linier berganda adalah sebagai berikut : 


\section{$J U R N A$
ANALISIS, PREDIKSI, DAN INFORMASI}

$$
Y=a+b_{1} X_{1}+b_{2} X_{2}+\cdots+b_{K} X_{K}
$$

Keterangan :

$\mathbf{Y}=$ Variabel Terikat

a $\quad=$ Harga Konstanta (Harga Y bila $\mathrm{X}=0$ )

$\boldsymbol{X}_{1}, \boldsymbol{X}_{2}, \boldsymbol{X}_{\boldsymbol{K}} \quad=$ Variabel Bebas

$\boldsymbol{b}_{1}, \boldsymbol{b}_{2}, \boldsymbol{b}_{\boldsymbol{K}} \quad=$ Angka arah atau koefisien regresi, yang menunjukkan angka

peningkatan ataupun penurunan variabel dependent yang didasarkan pada perubahan variabel independen. Bila $(+)$ maka terjadi kenaikan dan bila (-) maka terjadi penurunan.

\section{Uji Hipotesis}

\section{Uji t (Uji Signifikan Parsial)}

Uji t dilakukan untuk mengetahui faktor-faktor atau variabel-variabel bebas yang memiliki pengaruh secara parsial (sediri-sendiri) dan signifikan terhadap variabel dependen (terikat). Dengan tingkat error 5\%, maka hipotesis akan diterima jika nilai probabilitas signifikansi $<0,05$ dan jika nilainya $>0,05$, maka Hipotesis ditolak

\section{Uji f/ Uji ANOVA (Uji Signifikasi Simultan)}

Uji f atau Uji ANOVA yaitu uji untuk melihat pengaruh semua variabel independen (bebas) secara bersama-sama (simultan) terhadap variabel dependen.

Langkah pengujian uji f dengan derajat kepercayaan $95 \%$ probabilitas signifikansi $<0,05$, maka H0 diterima, jika > 0,05, maka H0 ditolak

\section{Koefisien Determinasi}

Hasil analisis dari Koefisiensi Determinasi $\left(\mathrm{R}^{2}\right)$ adalah untuk mengetahui seberapa jauh kemampuan sebuah model dalam menerangkan variasi variabel dependen. Nilai koefisien determinasi adalah antara nol dan satu. Nilai R2 yang kecil berarti kemampuan variabel-variable independen dalam menjelaskan variasi variabel dependen amat terbatas (Ghozali :2009).

\section{HASIL DAN PEMBAHASAN}

\section{Karakteristik Responden}

Pada tabel 5 menunjukkan bahwa dari 196 responden, terdapat 107 responden $(55 \%)$ berjenis kelamin laki-laki, dan sebanyak 89 responden $(45 \%)$ berjenis kelamin 


\section{JURNAAL

perempuan

Tabel 5. Jenis Kelamin

\begin{tabular}{|l|l|l|l|}
\hline No & Jenis Kelamin & Jumlah & Prosentase \\
\hline 1 & Laki - Laki & 107 orang & $55 \%$ \\
\hline 2 & Perempuan & 89 orang & $45 \%$ \\
\hline \multicolumn{2}{|c|}{ JUMLAH } & 196 orang & $\mathbf{1 0 0 \%}$ \\
\hline
\end{tabular}

Sumber : data diolah peneliti (2020)

Pada tabel 6, terkait dengan karakteristik usia responden menunjukkan bahwa dari 196 responden, terdapat 76 responden (39\%) berusia 26-35 tahun, 69 responden (35\%) berusia 36-45 tahun, 33 responden (17\%) berusia 16-25 tahun, dan sebanyak 18 responden $(9 \%)$ berusia $>45$ tahun.

Tabel 6. Usia

\begin{tabular}{|l|l|l|l|}
\hline No & \multicolumn{1}{|c|}{ Usia } & \multicolumn{1}{c|}{ Jumlah } & \multicolumn{1}{c|}{ Prosentase } \\
\hline 1 & $16-25$ tahun & 33 orang & $17 \%$ \\
\hline 2 & $26-35$ tahun & 76 orang & $39 \%$ \\
\hline 3 & $36-45$ tahun & 69 orang & $35 \%$ \\
\hline 4 & $>45$ tahun & 18 orang & $9 \%$ \\
\hline \multicolumn{2}{|c|}{ JUMLAH } & 196 orang & $\mathbf{1 0 0 \%}$ \\
\hline
\end{tabular}

Sumber : data diolah peneliti (2020)

Pada tabel 7, terkait dengan kunjungan yang telah dilakukan pasca erupsi 2014 pada kawasan Gunung Kelud, menunjukkan bahwa dari 196 responden, terdapat 78 responden (40\%) telah berkunjung sebanyak 1 kali, sebanyak 57 responden (29\%) telah berkunjung sebanyak 2 kali, sebanyak 39 responden (20\%) telah berkunjung sebanyak 3 kali, dan 22 responden $(11 \%)$ telah berkunjung sebanyak > 3 kali.

Tabel 7. Kunjungan ke Gunung Kelud

\begin{tabular}{|c|c|c|c|}
\hline No & Kunjungan & Jumlah & Prosentase \\
\hline 1 & $1 \mathrm{kali}$ & 78 orang & $40 \%$ \\
\hline 2 & 2 kali & 57 orang & $29 \%$ \\
\hline 3 & 3 kali & 39 orang & $20 \%$ \\
\hline 4 & $>3$ kali & 22 orang & $11 \%$ \\
\hline \multicolumn{2}{|c|}{ JUMLAH } & 196 orang & $100 \%$ \\
\hline
\end{tabular}




\section{Uji Normalitas}

Gambar 1 adalah hasil uji normalitas berdasarkan data ploting (titik-titik) yang menggambarkan data sesungguhnya mengikuti garis diagonal.

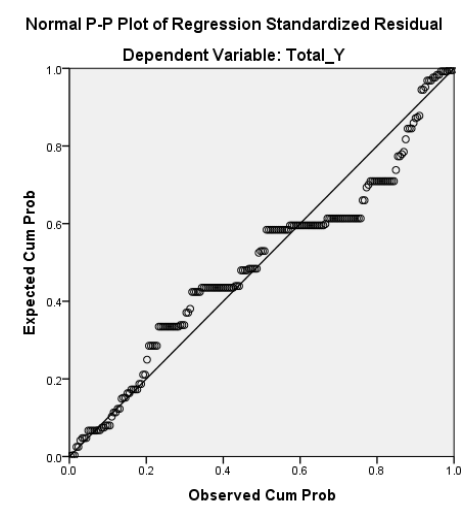

\section{Gambar 1. Hasil uji Normalitas}

\section{Uji Multikolinieritas}

Dari hasil perhitungan SPSS, seperti pada tabel 8, menunjukkan bahwa semua variabel memiliki nilai tolerance lebih besar dari 0,1 dan nilai VIF dibawah 10 , hal ini menunjukkan tidak terdapat gejala multikolinieritas. Hal tersebut sesuai dengan kriteria (Idris, 2010), yaitu angka tolerance $>0,1$ dan VIF $<10$ dikatakan tidak terdapat gejala multikolinearitas.

\section{Analisis Regresi Linier Berganda}

Berdasarkan hasil perhitungan data menggunakan SPSS seperti pada Tabel 8, maka bisa dirumuskan regresi linier berganda sebagai berikut :

$$
\mathrm{Y}=2,729+0,141 \mathrm{X} 1-0,207 \mathrm{X} 2+0,527 \mathrm{X} 3+0,124 \mathrm{X} 4+\mathrm{e}
$$




\section{JURNALL

\section{Uji Hipotesis Parsial (uji t)}

Tabel 8. Coefficients

\begin{tabular}{|c|c|c|c|c|c|c|c|}
\hline \multirow[b]{2}{*}{ Model } & \multicolumn{2}{|c|}{$\begin{array}{c}\text { Unstandardized } \\
\text { Coefficients }\end{array}$} & \multirow{2}{*}{$\begin{array}{c}\text { Standardized } \\
\text { Coefficients } \\
\text { Beta }\end{array}$} & \multirow[b]{2}{*}{$t$} & \multirow[b]{2}{*}{ Sig. } & \multicolumn{2}{|c|}{$\begin{array}{c}\text { Collinearity } \\
\text { Statistics }\end{array}$} \\
\hline & $\mathrm{B}$ & Std. Error & & & & Tolerance & VIF \\
\hline 1 (Constant) & 2.729 & .377 & & 7.249 & .000 & & \\
\hline Total_X1 & .141 & .041 & .212 & 3.484 & .001 & .370 & 2.699 \\
\hline Total_X2 & -.207 & .048 & -.208 & -4.270 & .000 & .578 & 1.731 \\
\hline Total_X3 & .527 & .049 & .586 & 10.836 & .000 & .470 & 2.130 \\
\hline Total_X4 & .124 & .020 & .308 & 6.168 & .000 & .551 & 1.815 \\
\hline
\end{tabular}

a. Dependent Variable: Total_Y

Berdasarkan Tabel 8 menunjukkan nilai Sig < 0,05 untuk semua variabel, hal tersebut berarti Variabel Moral Experience (X1), Educational Experience (X2), Experience Of Knowledge (X3), dan Personal Experience (X4) memiliki pengaruh secara parsial terhadap Variabel Revisit Intention (Y). Hasil ini sesuai dengan beberapa penelitian dahulu dari (Yan et al., 2016); (Zhang et al., 2016). Pada penelitian ini yang memiliki pengaruh paling dominan adalah variabel Knowledge Experience. Pembeda dalam penelitian ini adalah penerapan pada wisatwasn lokal di Indonesia, khususnya Jawa Timur.

\section{Uji Hipotesis Simultas (uji f)}

Tabel 9. ANOVAa

\begin{tabular}{|ll|r|r|r|r|l|}
\hline Model & & Sum of Squares & \multicolumn{1}{c|}{$\mathrm{df}$} & Mean Square & \multicolumn{1}{|c|}{ F } & Sig. \\
\hline 1 & Regression & 106.646 & 4 & 26.661 & 134.344 & $.000^{\mathrm{b}}$ \\
& Residual & 37.905 & 191 & .198 & & \\
& Total & 144.551 & 195 & & & \\
\hline
\end{tabular}

a. Dependent Variable: Total Y

b. "Predictors: (Constant), Total_X4,Total_X2, Total_X3, Total_X1"

Berdasarkan Tabel 9 menunjukkan nilai Sig $<0,05$, hal tersebut berarti Variabel Moral Experiecne (X1), Educational Experience (X2), Experience Of Knowledge (X3), dan Personal Experience (X4) memiliki pengaruh secara parsial terhadap Variabel Revisit Intention (Y). Hal ini sesuai dengan hasil penelitian dari (Zhang et al., 2016) bahwa pengalaman kognitif memiliki efek positif yang signifikan pada minat untuk berkunjung 
kembali. Hasil dari penelitian ini bisa menjadi tinjauan sebuah evolusi konsep pariwisata, khususnya terkait wisata gelap (Light, 2017) yang selama ini masih kurang dieksplorasi.

\section{IV.KESIMPULAN DAN SARAN}

\section{Kesimpulan}

Kesimpulan yang bisa diambil berdasarkan hasil penelitian yang telah dilakukan adalah, penelitian ini adalah pengalaman wisatawan yang terdiri dari Moral Experience, Education Experience, Knowledge Experience, dan Personal Experience, berpengaruh baik secara parsial maupun simultan terhadap minat berkunjung kembali pada kawasan wisata Gunung Kelud. Dari keempat variabel independen (variabel bebas), variabel yang memiliki pengaruh paling dominan adalah variabel Knowledge Experience.

\section{Saran}

Saran yang bisa diberikan bagi pemerintah Kabupaten Kediri, maupun pengelola lokasi kawasan wisata Gunung Kelud secara khusus adalah memberikan pengalaman wisata yang menarik kepada para wisatawan, khususnya terkait dengan pengetahuan kebencanaan, misal dengan membuat museum erupsi gunung Kelud. Saran bagi peneliti selanjutnya adalah mengembangkan penelitian ini dengan menambah variabel-variabel yang belum diteliti, atau dengan menambah jumlah responden, maka akan membuat hasil penelitian selanjutnya akan lebih akurat.

\section{UCAPAN TERIMA KASIH}

Terima kasih atas kepercayaan yang diberikan untuk melaksanakan penelitian bersumber dari pendanaan Hibah Simlitabmas dengan skema Penelitian Dosen Pemula (PDP). Terima kasih kepada sivitas Universitas Kadiri atas segala dukungan, baik berupa moril maupun fasilitas penunjang dalam menyelesaikan penelitin ini.

\section{DAFTAR PUSTAKA}

Biran, A., Poria, Y., \& Oren, G. (2011). Sought Experiences At (Dark) Heritage Sites. Annals of Tourism Research, 38(3), 820-841. 


\section{JURNA L \\ ANALISIS, PREDIKSI, DAN INFORMASI}

https://doi.org/10.1016/j.annals.2010.12.001

Dalton, D. (2015). Dark Tourism and Crime, 50, 255-256. https://doi.org/10.1016/j.tourman.2015.02.015

Fonseca, A. P., Seabra, C., \& Silva, C. (2016). Dark Tourism : Concepts , Typologies and Sites. Journal of Tourism Reserach \& Hospitality, 1-6. https://doi.org/http://dx.doi.org/10.4172/2324-8807.S2-002

Ghozali, I. (2005). Aplikasi Analisis Multivariate dengan SPSS. Semarang: Badan Penerbit UNDIP.

Idris. (2010). Aplikasi Model Analisis Data Kuantitatif dengan Program SPSS. Padang: FE-UNP.

Light, D. (2017). Progress in dark tourism and thanatourism research: An uneasy relationship with heritage tourism. Tourism Management, 61, 275-301. https://doi.org/10.1016/j.tourman.2017.01.011

Liputan6. (2019). Libur Lebaran, Ribuan Wisatawan Kunjungi Gunung Kelud Setiap Hari. Retrieved from https://www.liputan6.com/lifestyle/read/3985862/liburlebaran-ribuan-wisatawan-kunjungi-gunung-kelud-setiap-hari

Mauludi, A. (2016). Teknik Belajar Statistika 2. Jakarta: Alim's Publishing.

Nasution. (2011). Metode Research Penelitian Ilmiah. Jakarta: PT Bumi Aksara.

NUGROHO, A. (2019). Libur Natal, Lima Ribu Orang Padati Gunung Kelud. Retrieved from https://radarkediri.jawapos.com/read/2019/12/26/171836/libur-natal-limaribu-orang-padati-gunung-kelud

Pariwisata, K. (2015). Analisis Kesiapan Destinasi Dalam Rangka Pencapaian Target 20 Juta Wisman Pada Tahun 2019 2015. Jakarta.

Pariwisata, K., \& Statistik, B. P. (2017). Jumlah Kunjungan Wisatawan Mancanegara Menurut Pintu Masuk \& Kebangsaan 2016 - 2017, 1-3.

Pariwisata, S. S. (2019). Statistik Wisatawan Nusantara 2018. Jakarta: BPS RI. Retrieved from

https://www.bps.go.id/publication/2019/07/02/5249c2b645e21291b51dfc1a/statisti k-wisatawan-nusantara-2018.html

Podoshen, J. S. (2013). Dark tourism motivations : Simulation, emotional contagion and topographic comparison. Tourism Management, 35, 263-271. https://doi.org/10.1016/j.tourman.2012.08.002

Podoshen, J. S., Andrzejewski, S. A., Venkatesh, V., \& Wallin, J. (2015). New approaches to dark tourism inquiry: A response to Isaac. Tourism Management, xxx, 1-4. https://doi.org/10.1016/j.tourman.2015.05.008

Sari, S. M. (2016). Kunjungan Wisatawan ke Kota Kediri Ditarget 180.000 Per Tahun. Retrieved from https://traveling.bisnis.com/read/20160422/224/540833/kunjunganwisatawan-ke-kota-kediri-ditarget-180.000-per-tahun

Sujianto, agus E. (2009). Aplikasi Statistik dengan SPSS 16.0. Jakarta: Prestasi Pustaka Publisher.

Wikipedia. (2014). Gunung Kelud. In Wikipedia. Retrieved from https://id.wikipedia.org/wiki/Gunung_Kelud

Yan, B. J., Zhang, J., Zhang, H. L., Lu, S. J., \& Guo, Y. R. (2016). Investigating the motivation-experience relationship in a dark tourism space: A case study of the Beichuan earthquake relics, China. Tourism Management, 53, 108-121. 
https://doi.org/10.1016/j.tourman.2015.09.014

Zhang, H., Yang, Y., Zheng, C., \& Zhang, J. (2016). Too dark to revisit? The role of past experiences and intrapersonal constraints. Tourism Management, 54, 452-464. https://doi.org/http://dx.doi.org/10.1016/j.tourman.2016.01.002 